\title{
Importance of pesticides for lethal poisoning in India during 1999 to 2018: a systematic review
}

\author{
Ayanthi Karunarathne ${ }^{1}$, Ashish Bhalla ${ }^{2}$, Aastha Sethi ${ }^{1,3}$, Uditha Perera $^{4}$ and Michael Eddleston ${ }^{1 *}$ (D)
}

\begin{abstract}
Background: Poisoning is a major problem in India. However, there is little systematic information on the key poisons responsible for most deaths by geographical area and over time. We aimed to review the literature to identify the poison classes causing the greatest number of deaths in India over the last 20 years.

Methods: We performed a systematic literature review in Medline, Embase and Google Scholar (1999-2018), and Indian online medical journals, to find papers that reported deaths from all forms of poisoning in India, with last search 20 April 2020. We included epidemiological studies, observational studies, randomised trials, interventional studies, and case series published from 1999 to 2018 that showed the number of deaths and autopsy studies indicating the specific poisons or poison classes. Studies providing the case fatality for specific poisons or classes, which enabled calculation of the number of deaths, were also included. We excluded deaths due to animal bites and stings, ethanol or methanol poisoning, and gas inhalation as well as papers reporting a single death (case study of single patient). We grouped the papers into 5-year intervals and identified the two most common poison classes in each paper. We used descriptive statistics to summarise the findings over time based on the causative poison and the location of the study.
\end{abstract}

Results: We identified 186 papers reporting 16,659 poisoning deaths between 1999 and 2018. The number of publications per 5-year interval showed no clear trend over the period (48, 38, 67, and 36 for consecutive periods). Half of the deaths ( $n=8338,50.0 \%$ ) were reported during the first 5 years of the study (1999-2003), the number of deaths declining thereafter (to $n=1714$ in 2014-2018). Deaths due to pesticide poisoning (94.5\%) were dominant across the study period compared to other classes of poison [hair dye paraphenylenediamine poisoning (2.6\%), medicine overdose (1.4\%) or plant poisoning (1.0\%)]. Among the pesticides, aluminium phosphide was the most important lethal poison during the first 10 years before declining markedly; organophosphorus insecticides were important throughout the period, becoming dominant in the last decade as aluminium phosphide cases declined. Unfortunately, few papers identified the specific organophosphorus insecticide responsible for deaths.

\footnotetext{
* Correspondence: m.eddleston@ed.ac.uk

${ }^{1}$ Centre for Pesticide Suicide Prevention, and Pharmacology, Toxicology \& Therapeutics, University/BHF Centre for Cardiovascular Science, University of Edinburgh, Edinburgh, UK

Full list of author information is available at the end of the article
}

(c) The Author(s). 2021 Open Access This article is licensed under a Creative Commons Attribution 4.0 International License, which permits use, sharing, adaptation, distribution and reproduction in any medium or format, as long as you give appropriate credit to the original author(s) and the source, provide a link to the Creative Commons licence, and indicate if changes were made. The images or other third party material in this article are included in the article's Creative Commons licence, unless indicated otherwise in a credit line to the material. If material is not included in the article's Creative Commons licence and your intended use is not permitted by statutory regulation or exceeds the permitted use, you will need to obtain permission directly from the copyright holder. To view a copy of this licence, visit http://creativecommons.org/licenses/by/4.0/ The Creative Commons Public Domain Dedication waiver (http://creativecommons.org/publicdomain/zero/1.0/) applies to the data made available in this article, unless otherwise stated in a credit line to the data. 
Conclusion: Use of the published literature to better understand the epidemiology of lethal poisoning in India has clear limitations, including secular variation in publishing practices and interest in poisoning. Unfortunately, there are no long-term detailed, combination hospital and community studies from India to provide this information. In their absence, our review indicates that pesticides are the most important poison in India, with organophosphorus insecticides replacing aluminium phosphide as the key lethal poison after government regulatory changes in 2001 reduced the latter's lethality. Plant and hair dye poisoning and medicines overdose caused few deaths. Aluminium phosphide deaths mostly occurred in northern Indian states, whereas deaths from organophosphorus insecticide poisoning occurred throughout India. Paraquat poisoning has become a clinical problem in the last 10 years. Lethal pesticide poisoning remains alarmingly common, emphasising the need for additional regulatory interventions to curtail the burden of pesticide poisoning deaths in India. More detailed reporting about the specific pesticide involved in lethal poisoning will be helpful to guide regulatory decisions.

Keywords: Poisoning, Deaths, India, Aluminium phosphide, Pesticide

\section{Introduction}

Poisoning is a global public health problem. The World Health Organisation (WHO) estimates that nearly 250, 000 deaths occur globally due to poisoning each year, with pesticides alone causing 150,000 deaths [1]. Most poisoning deaths occur in lower- and middle-income countries (LMIC) [2]. The number of deaths occurring from particular poisons or poison classes varies from place to place, and over time, as a result of changes in access, effective and timely medical management, preventative measures, and regulatory policies.

Pesticide poisoning has been a major problem in India since at least 1958, when 100 people died after consuming flour contaminated with the organophosphorus (OP) insecticide parathion [3]. An estimated 230,000 suicides occur each year in India [4], of whom at least 70,000 (30\%) die from pesticide suicide [5]. Plant poisoning is well recognised with deaths occurring from suicide, homicide, and unintentional poisoning [6]. Datura ( $D a-$ tura metel) was the poison of choice in homicide in nineteenth century [6] while other plants currently implicated in self-poisoning include Cascabela thevetia, Cerbera manghas or odollam, and Cleistanthus collinis [7] (likely due to easy availability [6]). Medicine overdose is a major problem in the United States of America and many European counties $[8,9]$ but its role in India is considered minor $[7,10]$.

The National Poisons Information Centre (PIC), one of several poison centres in India, provides information over the phone concerning the diagnosis, and management of poisoning [11-13]. These calls indicate that pesticides, medicines, and plants are important poisons used across the country. However, the number of PIC calls per year is relatively small compared to the population of India and does not give a representative picture of the situation across the country or identify the poisons killing most people.

Comprehensive longitudinal prospective case series from several hospitals across the country, such as has been done for Sri Lanka [14-16], would be the ideal sources for information on causes of poisoning death over time, but such studies are only available from Chandigarh (for example ref. $[17,18]$ ). We therefore took a literature review approach, aiming to identify the most important poisons and poison classes for death in India over the last 20 years from the published literature.

\section{Methods}

We performed a systematic review to identify papers reporting poisons or poison classes responsible for poisoning deaths in India over the last two decades (19992018).

Two authors (AK, AS) independently searched Medline, Embase and Google Scholar, using the terms in all fields ((( poison OR poisoning) NOT (bite OR alcohol OR methanol)) AND India) AND (death OR mortality)). We also searched online Indian journal websites for relevant papers, including the Journal of Association of Physicians of India, Journal of Indian Academy of Forensic Medicine, Indian Journal of Paediatrics, Indian Journal of Public Health, and Journal of the Indian Medical Association. We limited the search to English language publications or those with an English language summary. The databases were last searched on 20 April 2020.

We looked at all modes of poisoning, including unintentional, occupational and intentional, involving agrochemical and industrial chemicals, toxic plants, and medicine poison classes.

\section{Inclusion criteria}

We included epidemiological studies, observational studies, randomised trials, interventional studies, and case series published from 1999 to 2018 that showed the number of deaths and autopsy studies indicating the specific poisons or poison classes. Studies providing the case fatality for specific poisons or classes, which 
enabled calculation of the number of deaths, were also included.

\section{Exclusion criteria}

Deaths due to animal bites and stings, ethanol or methanol poisoning, and gas inhalation were excluded from this study as well as papers reporting a single death (case study of single patient). Animal bites were not included in the study because the epidemiology and intent of envenoming is quite different to poisoning, the subject of this paper. The precise cause of acute death with alcohol or methanol toxicity is often unclear. Death may occur from chronic effects of alcoholism, such as variceal bleeding and cirrhosis. We therefore excluded these causes of death.

We screened the papers (UP \& AK), removed duplicates, grouped the papers into five-year periods (19992003, 2004-2008, 2009-2013, 2014-2018), and identified the two most common poisons or poison classes in each paper (typically responsible for $>90 \%$ of deaths). Papers reporting deaths for more than one study period were considered as separate publications for each of the study periods and the death numbers extracted for each study period. If the number of deaths for each year was not reported in the paper but for the entire duration of the study, we calculated the number of deaths for each of the relevant study periods. Papers that did not provide this information were excluded.

We looked at the number of papers reporting deaths from poisoning during each study period, extracted the two most common groups of poisons. We summarised the data using simple descriptive statistics according to the poisons causing the most deaths and grouped them as pesticide, medicine, plant or other poisoning. We used SPSS (version 24) for the analysis. We did not register the review or publish a protocol for this descriptive review of poisoning deaths in India.

\section{Results}

We identified 186 relevant publications reporting deaths from a specific poison or poison class in India during 1999 to 2018 (Fig. 1). The number of publications

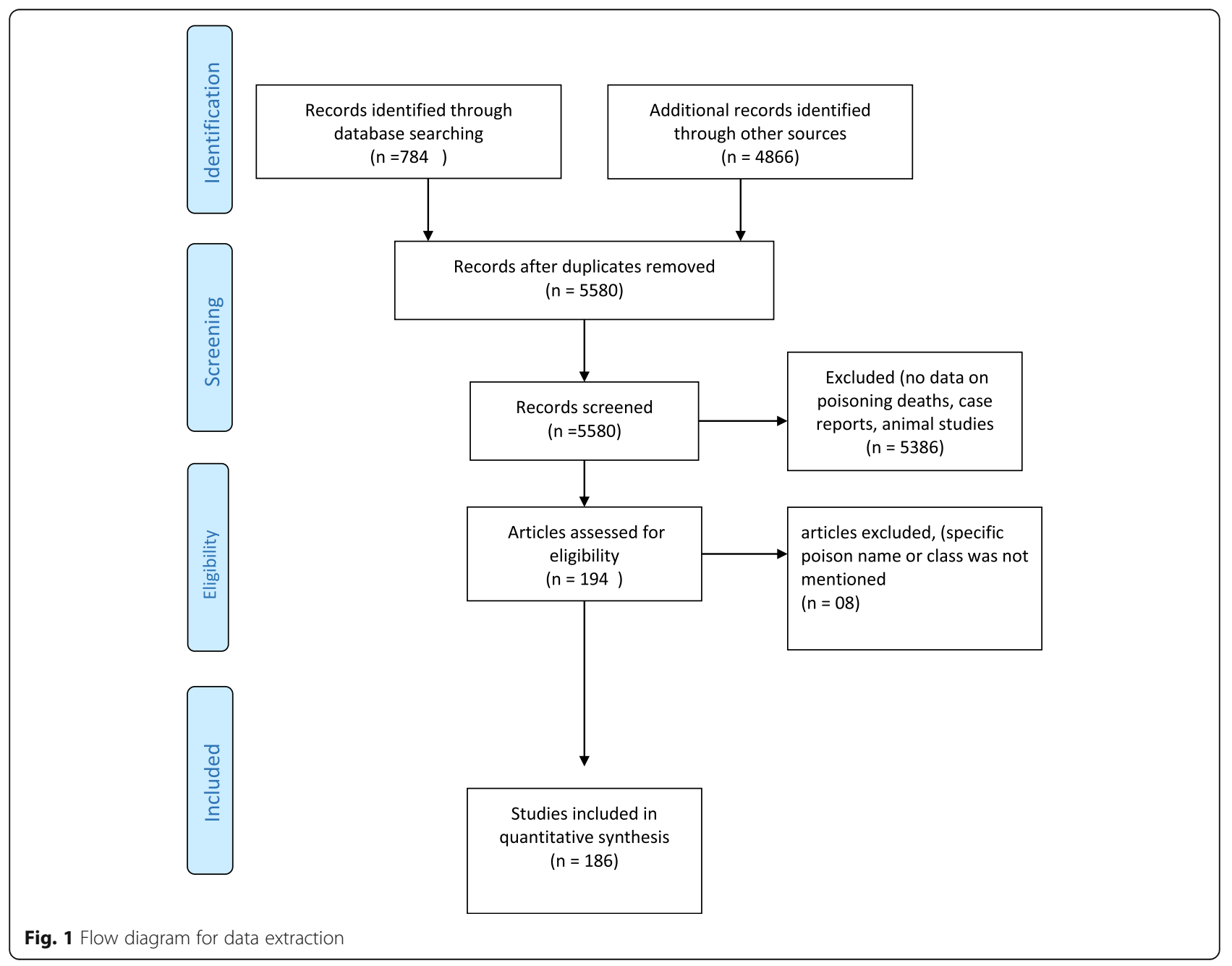


providing data for each 5-year interval showed no trend over the years: 1999-2003, $n=49$ [17, 19-67]; 2004$2008, n=38$ [26, 65, 67-102]; 2009-2013, $n=67$ [10, $65,67,100,103-166]$; and 2014-2018, $n=36$ [167-202] (mean 48.2, SD 13.45).

There were 16,659 deaths from the two most important poison classes in each paper (Table 1). Half of the deaths reported $(n=8338,50.0 \%)$ were for the 19992003 period while the least $(n=1714,10.2 \%)$ was reported for the most recent five-year period (2014-2018).

Most reported deaths $(n=15,748,94.5 \%)$ were due to pesticides, of which OP insecticides $(n=6387,40.5 \%)$ and aluminium phosphide $(n=5534,35.1 \%)$ were identified as being responsible for $75 \%$. Some papers classified deaths as only insecticides $(n=741)$ or pesticides $(n=$ 1806), preventing more specific identification of the causative poison. Aluminium phosphide was the most important poison in the first five-year period (3363 deaths) but then rapidly fell in importance, being reported in just 461 deaths in the last period (Fig. 2). OP insecticides were important throughout the two decades, being responsible for 2541 deaths in the first 5 years and 940 in the last 5 years. Unfortunately, relatively few papers reported the individual OP insecticides involved but commonly reported compounds included monocrotophos $[27,73,82,111,116]$ methyl parathion $[38,39,81$, 198], dimethoate [187], chlorpyrifos [187], quinalphos [141], dichlorvos [111], and phorate [158].

Table 1 Papers that reported more than 100 deaths from poison

\begin{tabular}{|c|c|c|c|c|}
\hline Year (mid study period) & location & Type of poisoning & Number of Deaths & Paper \\
\hline 2003 & Bhopal & Aluminium phosphide & 1455 & [19] \\
\hline 2001 & Rewa & Aluminium phosphide & 112 & [54] \\
\hline 2001 & Rewa & Aluminium phosphide & 122 & [53] \\
\hline 2001 & Chandigarh & Aluminium phosphide & 359 & [21] \\
\hline 1999 & Chandigarh & $\begin{array}{l}\text { Aluminium phosphide } \\
\text { Insecticide }\end{array}$ & $\begin{array}{l}327 \\
127\end{array}$ & [22] \\
\hline 1999 & Chandigarh & Aluminium phosphide & 595 & [24] \\
\hline 2000 & Ujjain & Organophosphate & 117 & {$[27]$} \\
\hline 2000 & West Bengal & Pesticide & 148 & [30] \\
\hline 2002 & Karnataka & Insecticide & 286 & [34] \\
\hline 2002 & Karnataka & Organophosphate & 187 & [35] \\
\hline 1999 & Yavatmal & $\begin{array}{l}\text { Pesticide } \\
\text { Organochlorine }\end{array}$ & $\begin{array}{l}526 \\
145\end{array}$ & {$[40]$} \\
\hline 1999 & Andra Pradesh & Pesticide & 228 & [47] \\
\hline 1998 & Tamil Nadu & Pesticide & 961 & [44] \\
\hline 2001 & Tamil Nadu & Pesticide & 258 & [45] \\
\hline 2007 & Jhansi & Hair dye (paraphenylenediamine (PPD) & 311 & [71] \\
\hline 2005 & Surat, & Pesticide & 116 & [74] \\
\hline 2004 & Yavatmal & Insecticide & 103 & [78] \\
\hline 2008 & Tamil Nadu & Pesticide & 149 & [81] \\
\hline 2008 & Chandigarh & Aluminium phosphide & 449 & [91] \\
\hline 2010 & Lucknow & Carbamate & 110 & [112] \\
\hline 2012 & Himachal Pradesh & Pesticide & 390 & [123] \\
\hline 2013 & Karnataka & Organophosphate & 245 & [137] \\
\hline 2012 & Karnataka & Organophosphate & 100 & [140] \\
\hline 2012 & Kerala & Organophosphate & 219 & [141] \\
\hline 2012 & Maharashtra & Organophosphate & 141 & [157] \\
\hline 2018 & Punjab & Aluminium phosphide & 403 & [169] \\
\hline 2016 & Kanpur & $\begin{array}{l}\text { Organophosphate } \\
\text { Organochlorine }\end{array}$ & $\begin{array}{l}139 \\
104\end{array}$ & [177] \\
\hline 2015 & Valsad & Organophosphate & 106 & [179] \\
\hline 2014 & Tamil Nadu & Organophosphate & 118 & [185] \\
\hline
\end{tabular}




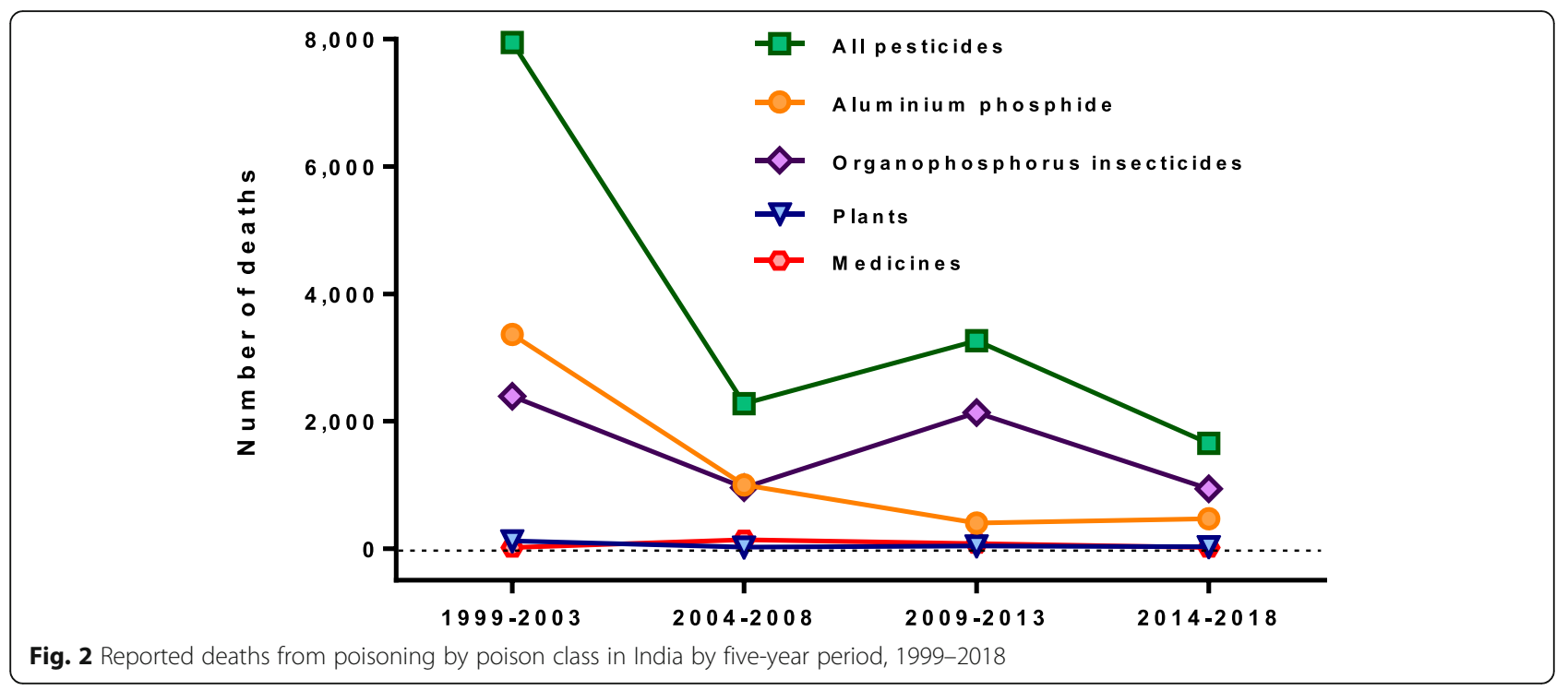

Organochlorine $(n=620)$, carbamate $(n=244)$ and pyrethroid $(n=25)$ insecticides, the herbicide paraquat $(n=305)$, rodenticides $(n=73)$, and fungicides $(n=14)$ were other pesticide classes that were identified as causing deaths. The most important organochlorine insecticide was endosulfan $[56,98]$ (after the ban of endrin in 1990 [203]). There were 233, 148, 101, and 138 deaths reported from organochlorines during the five periods, without any change in the last quarter after the nationwide ban of endosulfan in 2011. The paraquat deaths predominantly occurred during the 2009-2013 period ( $n=167,54.7 \%$ of total) with very few $(n=6,1.9 \%)$ reported prior to 2009.

Hair dye poisoning was the cause of 439 deaths $(2.6 \%$ of all reported deaths) during the middle decade, with 319 reported during 2004-2008 and 120 during 20092013. All were due to paraphenylenediamine (PPD) poisoning $[77,126-129,166]$, either in the generic form of stone hair dye or the branded Vasmol 33. It is unclear whether cases continued after 2013, in the absence of reports; no regulatory activities were identified to explain a reduction.

Other chemicals, such as kerosene and household chemicals (eg. bleach), caused 62 deaths during the study period.

Deaths reported as being due to medicines or toxic plants were substantially less common than pesticide poisoning. There were 240 deaths due to medicines, accounting for $1.4 \%$ of deaths. The medicines noted were anti-tuberculosis drugs $(n=62)$, barbiturates $(n=14)$, dextropropoxyphene $(n=11)$, dapsone $(n=3)$, and alternative/complementary medicines $(n=3)$.

Toxic plants were responsible for 201 deaths, with the number markedly higher in the first 5-year period
(1999-2003: 112; 2004-2008: 21; 2009-2013: 41; 20142018: 27). Cleistanthus collinis (oduvan, $n=131$ ), Cerbera odollam (sea mango, $n=52$ ), and Cascabela thevetia (yellow oleander, $n=16$ ) were the common plant poisons recorded to have caused deaths.

Aluminium phosphide poisoning had a marked geographical distribution. Of the 38 papers reporting it as the primary cause of deaths, 35 (92.1\%), reporting 4837 (99.4\%) deaths, were from northern Indian states (Haryana, Punjab, Uttar Pradesh, Gujarat, Madhya Pradesh). Only 3 reports (with just 27 deaths) were from the south, all from Karnataka state. An additional seven papers reported aluminium phosphide as a secondary cause of death in the south (Karnataka, Maharashtra, Tamil Nadu) but again only 124 deaths were included. Overall, 97.2\% (5079 deaths) of aluminium phosphide deaths occurred in the north compared to $2.8 \%(n=$ 146) in the south. This geographical distribution is due to this fumigant's use for preservation of wheat grain which is predominantly grown in the north [204].

In contrast, the total number of deaths from poisons other than aluminium phosphide was significantly higher in southern states of Andhra Pradesh, Maharashtra, Telangana, Tamil Nadu, Karnataka, Kerala, and Orissa, than the rest of the country $(n=6747,75.5 \%)$ vs $(n=2187$, 24,5\%) (Table 2).

The distribution of plant poisoning was also geographically restricted with cases of $C$ collinis, $C$ odollam, and $C$ thevetia poisoning all being reported from the south, especially Tamil Nadu and Kerala. Except for one large study reporting 311 deaths in Uttar Pradesh, all the studies reporting deaths from hair dye poisoning were from the southern states of Andhra Pradesh and Tamil Nadu. 
Table 2 Number of deaths reported in publications from each State by five-year period, 1999-2018

\begin{tabular}{lllll}
\hline State & $\mathbf{1 9 9 9 - 2 0 0 3}$ & $\mathbf{2 0 0 4 - 2 0 0 8}$ & $\mathbf{2 0 0 9 - 2 0 1 3}$ & $\mathbf{2 0 1 4 - 2 0 1 8}$ \\
\hline Andhra Pradesh +Telangana & 937 & 146 & 190 & $\mathbf{2}$ \\
Capital Territory of Delhi & 23 & 102 & 107 & $\mathbf{7}$ \\
Gujarat & 28 & 220 & 80 & $\mathbf{7 3}$ \\
Haryana & 1286 & 449 & 639 & 118 \\
Karnataka & 730 & 315 & 239 & 9 \\
Kerala & 46 & 57 & 0 & 37 \\
Madhya Pradesh & 1614 & 90 & 333 & 69 \\
Maharashtra & 1052 & 249 & 525 & 64 \\
Other & 56 & 15 & 339 & 403 \\
Punjab & 165 & 178 & 96 & 151 \\
Tamil Nadu & 1338 & 240 & 146 & 182 \\
Uttar Pradesh & 21 & 394 & 112 & \\
West Bengal & 208 & 4 &
\end{tabular}

\section{Discussion}

Poisoning has been a major clinical and public health problem in LMIC, including India, for decades although the burden has often been ignored [7]. Despite the underreporting of poisoning deaths in India due to weaknesses in death certification, stigma associated with suicide [205], and lack of clinical and laboratory services to aid diagnosis, we found an alarming number of deaths in the Indian literature. The vast majority were due to intentional pesticide poisoning, indicating the importance of regulating highly hazardous pesticides (HHPs) to prevent deaths as recommended by the $\mathrm{WHO}$ and FAO [206-209]. Continued global regulation of pesticides to remove HHPs from poor smallholder farms in LMICs, which are totally unable to use them safely, will rapidly reduce pesticide and total suicide rates [210, 211].

PIC data is useful for understanding the epidemiology of cases presenting to hospital, but cannot be used to assess the burden of poisoning deaths in India. PICs do not routinely collect data on the outcome of patients after a phone consultation. A prospective PIC call study in Sri Lanka showed that mortality was $<10 \%$ among cases reported to PIC [212]. Many of the patients discussed with PIC were not critically ill, with advice frequently being sought for mildly poisoned patients [213] PICs do not get called about all poisoning patients and frequent inquiries about one particular poison does not mean that it's a common cause of poisoning death in the community. The Sri Lankan national PIC receives 315 calls/year on average while poisoning hospital admissions exceed 80,000 - a 250-fold greater number of cases [212]. In Switzerland, only $11.4 \%$ of poisoned patients were referred to the PIC [213]. PICs are usually utilised for identification or management of unfamiliar poisonings and, even for these unusual presentations, information via telephone may not be a clinician's first choice. Doctors may be reluctant to seek assistance from non-clinicians in the PIC and prefer the internet over the telephone in obtaining such poisons information [214]. The availability of an online database (TOXBASE) in the United Kingdom has caused a dramatic decline in the telephone enquires [215]. The utilisation of web based resources for such poison related information will affect the representativeness of PIC data [216].

This Indian literature review provides some interesting information. Aluminium phosphide self-poisoning was first reported in north Indian states around Delhi in the 1980s [217-219] before becoming a major practically untreatable clinical problem with no antidote $[18,220]$. Remarkably, a change in the formulation of the fumigant in 2001, removing the $3 \mathrm{~g} \mathrm{56 \%}$ aluminium phosphide tablets from open sale [203], has resulted in a major reduction in deaths reported in the literature. This is supported by the single hospital study performed at Nehru Hospital, Chandigarh, in which the case fatality fell from $59 \%$ to $22 \%$ [17]. This appears to have been a great public health and pesticide regulatory success that could be replicated for OP insecticides. However, the situation seems to be different in Iran [221]. Despite a ban of aluminium phosphide tablets in 2007, fatal cases continued to be common in Iran. The incidence of fatal aluminium phosphide cases referred for phosphine analysis in Tehran increased from 5.2 per million population in 2006 to 37.0 in 2013. Aluminium phosphide was reported as being responsible for 2007 deaths during these 8 years, $85 \%$ from self-poisoning [221].

Deaths from OP insecticide poisoning were common throughout the study period, being only modestly less important than aluminium phosphide at the beginning and far more important at the end. The experience of 
Sri Lanka [222-224] and Bangladesh [225] has shown that bans of highly hazardous OP insecticides result in a rapid fall in pesticide suicides, without apparent effect on agricultural productivity [211, 225-227]. The Indian government banned the key OP insecticide parathion in 1974 after recognising its important role in fatal poisoning $[203,228]$. Monocrotophos was banned from vegetable production in 2005; however, this restriction is not widely enforced and it remains commonly used in small scale agriculture $[229,230]$ and therefore self-harm.

The Indian government banned 18 pesticides in 2018 and 2020 [231], including several highly hazardous OP insecticides used for self-harm (fenthion, methyl parathion, dichlorvos, phorate, phosphamidon, and triazophos). These regulations have the potential to markedly reduce deaths from poisoning across India; its effects on suicide, occupational poisoning and agricultural output needs to be carefully monitored. The Government has recently proposed banning another 27 pesticides, including monocrotophos and dimethoate which are acutely toxic pesticides when used for self-poisoning.

The organochlorine insecticide endrin was responsible for many deaths in the 1960s-80s until being banned in 1990 [203]. Endosulfan was thereafter a major problem until it too was banned in Kerala in 2005 and across India in 2011; the effect of this ban is unclear from these data since the number of cases reported during the last 10 years remained quite steady. Illegal importation of some endosulfan, despite the ban, might be partially responsible [232]. Organochlorine insecticide deaths are still in reported in some states of India (Rajasthan, Andhra Pradesh, Karnataka, Tamil Nadu) [233]. The effects of the endosulfan ban, driven by the Indian $\mathrm{Su}-$ preme Court [234], should be carefully studied, although initial analyses using national police data suggest that it may have been associated with a national fall in pesticide suicides [203].

We found relatively few deaths from herbicides, including paraquat; they were responsible for just $1.8 \%$ of all reported pesticide deaths. This runs counter to claims that herbicides have been commonly taken in suicide attempts in India [100]. However, there was an increasing trend in paraquat poisoning in India. A hospital based study performed during 1999-2006 reported five patients (three deaths) in Punjab [28], while a second from Tamil Nadu reported ten patients with $100 \%$ mortality [235]. A recent newspaper report states that paraquat poisoning is a problem in Orissa with more than 100 deaths reported during 2018 and 2019 [236]. If paraquat becomes widely used for agriculture and self-harm in India, there is the risk of a massive increase in deaths as occurred in China before its ban in 2016.

Fatal plant poisoning with $C$ collinus, $C$ odallam, and $C$ thevetia were relatively uncommon. The number was greatest in the first 5 years of study, before falling steadily by $75 \%$. Most cases were suicides and occurred in rural regions of south Indian states. It is possible that medical therapy has improved with experience.

Medicine poisoning deaths are not uncommon in high income countries, especially where medical opioid addiction is widespread [237]. An increase in the number of cases of medicine poisoning has been reported from urban Sri Lanka [238] but we found few deaths in this study, likely due to the relatively low case fatality of medicine poisoning [7]. The incidence of medical opioid addiction currently seems low in India [239].

Dextropropoxyphene has long been used as an analgesic, alone or in combination with paracetamol (acetaminophen). However, many European countries including England and Scotland banned its use during 2005-2009 due to its importance for suicide [240]. Based on these findings, the central government of India suspended its manufacture, sale and distribution in 2013 [240]. The deaths from dextropropoxyphene reported in this study occurred in 2011-2012 [113], before its ban.

\section{Limitations}

The use of the published literature from multiple hospitals over 20 years to get a better understanding of the epidemiology of lethal poisoning in India has clear limitations. Secular variation in publishing practices and interest in poisoning possible are two of them. The best approach would be to have a network of sentinel hospital sites across India collecting prospective data and reporting their experience with both hospital cases and poisoning deaths that occur in their communities, before hospital admission, as recommended by the WHO [241]. This would allow for systematic collection of data that should allow interpretation of changes over time, especially in response to regulatory changes. Unfortunately, there is no network of such sentinel sites in India, although a few hospitals have reported their experience over the medium term (for example the Nehru Hospital, Chandigarh).

A further key limitation is that our review is based on papers in English and available online, which means we will have missed studies in other Indian language and papers that were not available online. A number of studies reporting results in other Indian languages did have abstracts in English, but this lacked the detailed information required for the review. However, the large number of studies found (186 papers, 16,659 deaths) suggests that these additional papers are unlikely to have changed its key conclusions.

All the studies included here were either from a healthcare facility or a forensic autopsy study. Therefore, patients who die before reaching hospitals may not be fully represented in these studies (although forensic case 
series usually include deaths occurring pre-hospital). The importance of under-reporting of suicides is clearly shown by verbal autopsy studies [242] which show markedly higher rates of suicide than reported in government statistics. It is therefore possible that a fastacting poison, which kills people before they get to hospital, may be under-represented in this analysis. Many studies were of hospitalised patients in a few selected institutes; the vast majority of hospitals seeing such patients do not publish their experience, suggesting some bias. Many poisoning patients leave hospital against medical advice preventing any follow up, resulting in underreporting of some deaths. Extrapolating police records on poisoning autopsies and poisoning death data from forensic studies would be useful to gain a fuller picture of poisoning deaths in India.

Since we wished to get a broad-brush picture of lethal poisoning, we did not include every lethal case in the papers identified but only the two most common causes. This means that relatively uncommon poisons such as plants and medicines will be under-represented in the total picture. However, in very few papers did these poisons make up more than $5 \%$ of the lethal cases and so including all the deaths in all 186 papers would unlikely have changed the conclusions.

For the above reasons, in particular the lack of data on prevalence or incidence, as well as population and region, the data did not allow a State- or period-based calculation of the incidence of lethal poisoning or for a sexand age-based analysis. The number of cases reported in the literature is likely to be a small sub-sample of all deaths occurring. Indeed, Patel and colleagues estimated that poisoning accounts for about 70,000 deaths every year in India [5] compared to the 833 deaths/year reported in this systematic review.

\section{Conclusion}

In this study of the literature, we found that pesticide poisoning was a major cause of death in India throughout the study period, although aluminium phosphide appears to have become much less important after government regulation. Similar government regulation is underway for OP insecticides, which could have a major effect on the number of poisoning deaths over the next few years. Deaths from plant and medicine poisoning remain uncommon.

\section{Abbreviations}

WHO: World Health Organisation; LMIC: Lower- and Middle-Income Countries; HHP: Highly Hazardous Pesticides; OP: Organophosphorus; PIC: Poison Information Centre; FAO: Food and Agriculture Organisation

\section{Authors' contributions}

ME conceptualised and designed the study. AK and AS performed the online search separately. UP and AK screened and selected the papers. AK extracted the data and did the analysis. AK, ME and UP drafted the Manuscript. AB contributed to the writing of the manuscript. All authors read and approved the final manuscript.

\section{Funding}

The Centre for Pesticide Suicide Prevention is funded by an Incubator Grant from the Open Philanthropy Project Fund, an advised fund of Silicon Valley Community Foundation, on the recommendation of GiveWell, USA.

The funders of the study had no role in study design, data collection, data analysis, data interpretation, or writing of the report. The corresponding author had full access to all the data in the study and final responsibility for the decision to submit for publication.

\section{Availability of data and materials}

All data are available online as given in the reference list.

\section{Declarations}

Ethics approval

Used secondary data therefore ethical approval was not sought.

Consent for publication

Not applicable.

\section{Competing interests}

The authors declare no conflict of interest.

\section{Author details}

${ }^{1}$ Centre for Pesticide Suicide Prevention, and Pharmacology, Toxicology \& Therapeutics, University/BHF Centre for Cardiovascular Science, University of Edinburgh, Edinburgh, UK. ${ }^{2}$ Department of Internal Medicine, Nehru Hospital, Institute of Medical Education and Research, Chandigarh, India. ${ }^{3}$ Government of Maharashtra, Mumbai, Maharashtra, India. ${ }^{4}$ Usher Institute for Population Health Sciences \& Informatics, University of Edinburgh, Edinburgh, UK.

Received: 18 September 2020 Accepted: 27 May 2021

Published online: 22 July 2021

\section{References}

1. World Health Organization. Guidelines for establishing a poison centre. Geneva: WHO: 2020

2. Karunarathne A, Gunnell D, Konradsen F, Eddleston M. How many premature deaths from pesticide suicide have occurred since the agricultural green revolution? Clin Toxicol. 2020;58(4):227-32.

3. Gupta P. Pesticide exposure-Indian scene. Toxicology. 2004;198(1-3):83-90

4. Dandona R, Kumar GA, Dhaliwal R, Naghavi M, Vos T, Shukla D, et al. Gender differentials and state variations in suicide deaths in India: the global burden of disease study 1990-2016. Lancet Public Health. 2018;3(10):e47889.

5. Patel V, Ramasundarahettige C, Vijayakumar L, Thakur J, Gajalakshmi V, Gururaj $\mathrm{G}$, et al. Suicide mortality in India: a nationally representative survey. Lancet. 2012;379(9834):2343-51.

6. Anon. Poisoning in India. Br Med J. 1892;2(1655):641-2

7. Eddleston M. Patterns and problems of deliberate self-poisoning in the developing world. Qjm. 2000;93(11):715-31.

8. Jones CM, Mack KA, Paulozzi $\sqcup$. Pharmaceutical overdose deaths, United States, 2010. JAMA. 2013;309(7):657-9.

9. van Amsterdam J, van den Brink W. The misuse of prescription opioids: a threat for Europe? Curr Drug Abuse Rev. 2015;8(1):3-14.

10. Anthony L, Kulkarni C. Patterns of poisoning and drug overdosage and their outcome among in-patients admitted to the emergency medicine department of a tertiary care hospital. Indian J Crit Care Med. 2012;16(3):130.

11. Peshin SS, Srivastava A, Halder N, Gupta YK. Pesticide poisoning trend analysis of 13 years: a retrospective study based on telephone calls at the National Poisons Information Centre, all India Institute of Medical Sciences, New Delhi. J Forensic Legal Med. 2014;22:57-61.

12. Srivastava A, Peshin SS, Kaleekal T, Gupta SK. An epidemiological study of poisoning cases reported to the national poisons information Centre, all India Institute of Medical Sciences, New Delhi. Hum Exp Toxicol. 2005;24(6): $279-85$. 
13. All India institute of medical sciences: 63rd AllMS annual report 2018-2019 In: https://www.aiims.edu/images/pdf/annual_reports/annual\%20report19e-20-1-20.pdf. Accessed 14 June 2021.

14. Dawson AH, Eddleston M, Senarathna L, Mohamed F, Gawarammana I, Bowe SJ, et al. Acute human lethal toxicity of agricultural pesticides: a prospective cohort study. PLoS Med. 2010;7(10):e1000357.

15. Weerasinghe $M$, Pearson M, Konradsen F, Agampodi S, Sumith J, Jayamanne $S$, et al. Emerging pesticides responsible for suicide in rural Sri Lanka following the 2008-2014 pesticide bans. BMC Public Health. 2020;20:1-8.

16. Buckley NA, Fahim M, Raubenheimer J, Gawarammana IB, Eddleston M, Roberts MS, Dawson AH. Case fatality of agricultural pesticides after selfpoisoning in Sri Lanka: a prospective cohort study. The Lancet Global Health. 2021:9(6):e854-62.

17. Murali R, Bhalla A, Singh D, Singh S. Acute pesticide poisoning: 15 years experience of a large North-West Indian hospital. Clin Toxicol (Philadelphia, Pa). 2009;47(1):35-8.

18. Singh $\mathrm{D}$, Jit I, Tyagi S. Changing trends in acute poisoning in Chandigarh zone: a 25-year autopsy experience from a tertiary care hospital in northern India. Am J Forensic Med Pathol. 1999:20(2):203-10.

19. Jain AK, Dubey B, Garg S, Nigam M. Trends of aluminium phosphide poisoning in Bhopal region-a retrospective study of 10 years. J Indian Acad Forensic Med. 2009;31(3):234-6.

20. Gargi J, Tejpal H, Chanana A, Rai G, Chaudhary R. A retrospective autopsy study of poisoning in the northern region of Punjab. J Punjab Acad Forensic Med Toxicol. 2008;8(2):17-9.

21. Harish D, Sharma B, Chavali K, Sharma A. Poisoning mortality in Chandigarh: an overview. J Indian Acad Forensic Med. 2006;28(3):110-3.

22. Sharma B, Singh VP, Sharma R. Unnatural deaths in northern India-a profile. J Indian Acad Forensic Med. 2004;26(4):140-6.

23. Zariwala RC, Merchant SP, Mehta T, Bhise R. Trends of poisoning in Ahmedabad. J Indian Acad Forensic Med. 2009;31(2):125-32.

24. Singh D, Tyagi S, Bansal YS, Mandal S, Thind A. Aluminium phosphide fatalities: a 24 years experience. J Indian Acad Forensic Med. 2007;29(1):971-3.

25. Hari P, Jain Y, Kabra SK. Fatal encephalopathy and renal failure caused by diethylene glycol poisoning. J Trop Pediatr. 2006;52(6):442-4.

26. Jayashree $M$, Singhi S. Changing trends and predictors of outcome in patients with acute poisoning admitted to the intensive care. J Trop Pediatr. 2011:57(5):340-6.

27. Nigam M, Jain AK, Dubey B, Sharma V. Trends of organophosphorus poisoning in Bhopal region an autopsy based study. J Indian Acad Forensic Med. 2004;26(2):62-5.

28. Agarwal R, Srinivas R, Aggarwal A, Gupta D. Experience with paraquat poisoning in a respiratory intensive care unit in North India. Singap Med J. 2006;47(12):1033-7.

29. Sandhu J, Dhiman A, Mahajan R, Sandhu P. Outcome of paraquat poisoning-a five year study. Indian J Nephrol. 2003;13:64-8.

30. Chowdhury AN, Banerjee S, Brahma A, Weiss MG. Pesticide practices and suicide among farmers of the Sundarban region in India. Food Nutr Bull. 2007:28(2_suppl2):S381-91.

31. Gaillard Y, Krishnamoorthy A, Bevalot F. Cerbera odollam: a 'suicide tree'and cause of death in the state of Kerala, India. J Ethnopharmacol. 2004;95(2-3):123-6.

32. Subrahmanyam D, Mooney T, Raveendran R, Zachariah B. A clinical and laboratory profile of Cleistanthus collinus poisoning. J Assoc Physicians India. 2003;51:1052-4.

33. Shankar V, Jose V, Bangdiwala SI, Thomas K. Epidemiology of Cleistanthus collinus (oduvan) poisoning: clinical features and risk factors for mortality. Int J Inj Control Saf Promot. 2009;16(4):223-30.

34. Rao DS. Sudden and unexpected natural deaths-a four-year autopsy review. J Punjab Acad Forensic Med Toxicol. 2008;8(2):20-4.

35. Kanchan T, Menon A, Menezes RG. Methods of choice in completed suicides: gender differences and review of literature. J Forensic Sci. 2009; 54(4):938-42.

36. Srinivas Rao C, Venkateswarlu V, Surender T, Eddleston M, Buckley NA Pesticide poisoning in South India: opportunities for prevention and improved medical management. Tropical Med Int Health. 2005;10(6):581-8.

37. Shivakumar S, Raghavan K, Natarajan S, Ishaq RM, Geetha S. Acute severe organophosphorus poisoning-role of serum cholinesterase. J Assoc Physicians India. 2003;51:1199.

38. Palimar V, Arun M, Mohan Kumar T, Saralaya K. Intermediate syndrome in organophosphorous poisoning. J Indian Acad Forensic Med. 2005; 27(1):28-30.
39. Vikram P, Arun M, Saralaya K, Bhoopendra S. Spectrum of organophoshorous poisoning in Manipal. Medico-legal update. 2005;5(2): 55-7.

40. Batra A, Keoliya A, Jadhav G. Poisoning: an unnatural cause of morbidity and mortality in rural India. J Assoc Physicians India. 2003;51:955-9.

41. Palimar V, Arun M, Bhagavanth $P$, Babu YR, Mohanty MK. Fatal deliberate self harm in geriatrics. J Indian Acad Forensic Med. 2006;28(4):177-9.

42. Singh B, Unnikrishnan B. A profile of acute poisoning at Mangalore (South India). J Clin Forensic Med. 2006;13(3):112-6.

43. Kanchan T, Menezes RG, Kumar TM, Bakkannavar SM, Bukelo MJ, Sharma PS et al. Toxicoepidemiology of fatal poisonings in southern India. J Forensic Legal Med. 2010;17(6):344-7.

44. Gajalakshmi V, Peto R. Suicide rates in rural Tamil Nadu, South India: verbal autopsy of 39000 deaths in 1997-98. Int J Epidemiol. 2007;36(1):203-7.

45. Bose A, Konradsen F, John J, Suganthy P, Muliyil J, Abraham S. Mortality rate and years of life lost from unintentional injury and suicide in South India. Tropical Med Int Health. 2006;11(10):1553-6.

46. Vidyasagar J, Karunakar N, Reddy M, Rajnarayana K, Surender T, Krishna D. Oxidative stress and antioxidant status in acute organophosphorous insecticide poisoning. Indian J Pharmacol. 2004;36(2):76.

47. Mohanty MK, Pinnamaneni S, Arun M, Menezes RG, Palimar V. Correlation between postmortem diagnosis and survival time in poisoning deaths. J Indian Acad Forensic Med. 2005;27(1):23-7.

48. Dash SK, Mohanty MK, Mohanty S, Patnaik KK. Organophosphorus poisoning: victim specific analysis of mortality and morbidity. Med Sci Law. 2008;48(3):241-5.

49. Kumar A, Singh P, Midha T. The study of changes in serum electrolytes ( $\mathrm{Na}+$ , $\mathrm{K}+, \mathrm{ca}++, \mathrm{mg}++)$ in alumninum phosphide poisonong patients-is there any correlation with mortality or survival ? J Evol Med Dent Sci. 2018;7(21): 2581-3.

50. Multani A, Bal B, Singh S, Singh T, Shivcharan SS. Spectrum of acute poisoning in medical emergencies-a prospective study. J Assoc Physicians India. 2003;51:1199-200.

51. Bogle R, Theron P, Brooks P, Dargan P, Redhead J. Aluminium phosphide poisoning. Emerg Med J. 2006;23(1):e03.

52. Vijayanath $\mathrm{V}$, Anitha M, Raju G, Vijayamahantesh S. Forensic view on aluminium phosphide poisoning. J Indian Acad Forensic Med. 2011;33(4): 289-91.

53. Shrivastava P, Baghel PK, Jain MK. A study of clinical profile in aluminium phosphide poisoning with special reference to hepatic changes. In: APICON, vol. 48. New Delhi: JAPl; 2003. p. 1-208.

54. Gupta A, Indurkar M. Predictability of ECG changes and blood pressure at the time of admission and its correlation to histopathological changes in heart in aluminium phosphide poisoning. In: APICON 2001, vol. 48. New Delhi: JAPI; 2001. p. 1-202.

55. Kumar PR, Rizvi SNA, Sharma S, Baishya RN, Prasad S. Haemodialysis and critical care in poisonings. In: APICON, 2003, vol. 50. New Delhi: JAPI; 2003. p. 1-208.

56. Dominique SK. Role of chemical examination in formation of opinion as to cause of death following poisoning. J Indian Acad Forensic Med. 2007;27(1): 28-31.

57. Chaudhuri S, Kar JK, Basu K, Dhar MS, Das S. Profile of acute poisoning in West Bengal - a rural medical college experience. In: APICON 2003, vol. 50. New Delhi: JAPl; 2003.

58. Kundu KA, Mukhopadhyay JD, Saha AK, Das S. Predictors of mortality in organophosphorus (op) compound poisoning - hospital-based study from suburban West Bengal. In: APICON 2001. New Delhi: JAPl; 2001. p. 1-202.

59. Das SN, Agrawal B, Dash PC, Dalai RK, Jali SN, Dash LK. Clinical profile of acute poisoning in hospitalised patients. In: APICON 2003, vol. 50. New Delhi: JAPI; 2003. p. 1-206.

60. Das BN, Behera GC, Das BP, Mohapatra BN, Patra UC, Mohanty S. Clinical, electrophysiological and histopathological study in acute organophosphorus poisoning. In: APICON 2001, vol. 48. New Delhi: JAPI; 2001. p. 1-202.

61. Polirnar V, Kumar PG. Poisoning deaths in children. J Indian Acad Forensic Med. 2009;31(3):218-21.

62. Shivakumar S, Shanmugasundaram N, Kumar SS. The psychosocial profile of acute poisoning in adults - a study of 253 cases. In: APICON 2003, vol. 50. New Delhi: JAPl; 2003. p. 1-208.

63. Gupta P, Gupta OMK, Alam SM, Dwivedi RN, Agarwal BD, Chandani AL. Serum electrolytes ( $\mathrm{na}+\mathrm{k}+\mathrm{ca}++, \mathrm{mg}++$ ) changes in aluminium phosphide (ALP) poisoning. In: APICON 2001, vol. 48. New Delhi: JAPI; 2001. p. 1-202. 
64. Garg B, Kajal HL, Kajal KS, Gupta PD. A retrospective analysis of 1000 consecutive cases of acute poisoning. In: APICON 2003, vol. 50. New Delhi: JAPI; 2003. p. 1-208.

65. Mohan A, Naik GS, Harikrishna J, Kumar DP, Rao M, Sarma K, et al. Cleistanthus collinus poisoning: experience at a medical intensive care unit in a tertiary care hospital in South India. Indian J Med Res. 2016;143(6):793.

66. Jain AK, Nigam M, Garg S, Dubey B, Arora A. Aluminium phosphide poisoning autopsy findings. J Indian Acad Forensic Med. 2005;27(1):35-9.

67. Siddamsetty A, Kumar A, Aggarwal N, Kumar A. Poisoning death trends in north East Delhi-a retrospective study. J Indian Acad Forensic Med. 2016; 38(2):213-6.

68. Singh O, Javeri Y, Juneja D, Gupta M, Singh G, Dang R. Profile and outcome of patients with acute toxicity admitted in intensive care unit: experiences from a major corporate hospital in urban India. Indian J Anaesth. 2011;55(4):370.

69. Khurana P, Gupta A. The study of CNS manifestations in aluminium phosphide poisoning. J Indian Acad Forensic Med. 2015;37(3):272-4

70. Khurana P, Dalal J, Multani A, Tejpal $H$. The study of aluminium phosphide poisoning in a tertiary care hospital, Amritsar. J Indian Acad Forensic Med. 2011;33(4):330-4.

71. Jain P, Agarwal N, Kumar P, Sengar N, Agarwal N, Akhtar A. Hair dye poisoning in Bundelkhand region (prospective analysis of hair dye poisoning cases presented in department of medicine, MLB medical college, Jhansi). J Assoc Physicians India. 2011;59(7):415-9.

72. Basu M, Kundu T, Dasgupta M, Das D, Saha I. Poisoning, stings and bites in children--what is new? An experience from a tertiary care hospital in Kolkata. Indian J Public Health. 2009;53(4):229-31.

73. Prajapati T, Prajapati K, Tandon R, Merchant S. A study of acute poisoning cases excluding animal bites at civil hospital, Ahmedabad. J Indian Acad Forensic Med. 2013;35(2):120-2

74. Gupta S, Kumar S, Sheikh M. Study of organophosphorus poisoning in Surat, India. J Indian Acad Forensic Med. 2006;28(3):83-7.

75. Pawar CK, Rai G, Chanana A, Pawar G, Kumar K, Kaul M, et al. Analysis of deaths due to poisoning: a two year retrospective study. J Indian Acad Forensic Med. 2017;39(3):298-302

76. Bardale R, Dixit P, Shrigiriwar M. Clinico-pathological profile of ethylene dibromide poisoning. J Indian Acad Forensic Med. 2006;28(3):105-7.

77. Sahay M, Vani R, Vali S. Hair dye ingestion--an uncommon cause of acute kidney injury. J Assoc Physicians India. 2009;57:743-4.

78. Vaidya YP, Hulke SM. Study of trends of poisoning in the cases reported to government hospital, Yavatmal. Chron young sci. 2012;3(1):63.

79. Devarbhavi H, Patil M, Reddy W, Singh R, Joseph T, Ganga D. Drug-induced acute liver failure in children and adults: results of a single-Centre study of 128 patients. Liver Int. 2018;38(7):1322-9.

80. Devarbhavi H, Raj S, Aradya VH, Rangegowda VT, Veeranna GP, Singh R, et al. Drug-induced liver injury associated with stevens-Johnson syndrome/ toxic epidermal necrolysis: patient characteristics, causes, and outcome in 36 cases. Hepatology. 2016;63(3):993-9.

81. Siddapur KR, Pawar GS, Mestri SC. Trends of poisoning and gross stomach mucosal appearance in fatal poisoning cases: an autopsy study. J Indian Acad Forensic Med. 2011;33(2):106-11.

82. Guntheti BK, Singh UP. The pattern of poisoning in Khammam. J Indian Acad Forensic Med. 2011;33(4):296-300.

83. Guntheti BK, Khaja S, Panda S. A study of serum cholinesterase levels in organo phosphorous poisoning cases. Governing Council 2010-2012. 2010;32:332.

84. Indu T, Raja D, Ponnusankar S. Toxicoepidemiology of acute poisoning cases in a secondary care hospital in rural South India: A 5-year analysis. J Postgrad Med. 2016;62(1):48-9.

85. Kumar C, Nayak GH, Biradar SS, Sudhan SM, Karlawad M, Selvan M. Trends of death due to poisoning among females at a tertiary care Centre in North Karnataka. Indian J Forensic Med Toxicol. 2019;13(1):67-71.

86. Kar N. Lethality of suicidal organophosphorus poisoning in an Indian population: exploring preventability. Ann General Psychiatry. 2006:5(1):17.

87. Jesslin J, Adepu R, Churi S. Assessment of prevalence and mortality incidences due to poisoning in a south Indian tertiary care teaching hospital. Indian J Pharm Sci. 2010;72(5):587.

88. Patel DJ, Tekade PR. Profile of organophosphorus poisoning at maharani hospital, Jagdalpur, Chhattisgarh: a three years study. J Indian Acad Forensic Med. 2011;33(2):102-5.

89. Prajapati T, Prajapati K, Tandon R, Merchant S. Acute chemical and pharmaceutical poisoning cases treated in civil hospital, Ahmedabad: one year study. Asia Pac J Med Toxicol. 2013;2(2):63-7.
90. Gupta B, Hapani J, Shah V. Current trend of poisoning in Jamnagar: an experience of tertiary care teaching hospital. J Indian Acad Forensic Med. 2006;28(3):90-2.

91. Singh A, Harish D, Kumar A. Aluminium phosphide, the most preferred poison: a 10 year retrospective study of deaths due to poisoning in a tertiary care center. J Punjab Acad Forensic Med Toxicol. 2013;13(2):74-9.

92. Kapoor A, Sinha U, Singh A, Mehrotra R. An epidemiological study of aluminium phosphide poisoning at Allahabad. Indian Internet J Forensic Med Toxicol. 2006;4(1):1-4

93. Sisodiya S, Gupta HO, Sharma B, Chaurasia KA, Jain MK, Rewa SSMC MI. Cardiovascular evaluation of patient of aluminium phosphide and ethylene dibromide poisoning. In: APICON 2010, vol. 58. New Delhi: JAPI; 2010. p. 1-206.

94. Varma NM, Kalele S. Study of profile of deaths due to poisoning in Bhavnagar region. J Indian Acad Forensic Med. 2011;33(4):311-6.

95. Sutay SS, Tirpude B. Pattern of histo pathological changes of liver in poisoning. J Indian Acad Forensic Med. 2008;30(2):63-8.

96. Siddaramanna T, Kumar RD, Rudramurthy S. Deaths due to organophosphorus poisoning-a retrospective study. J Indian Acad Forensic Med. 2016;38(3):278-9.

97. Celine TM, Antony J. A profile of acute poisonings: a retrospective study. J Sci Soc. 2015;42(3):156.

98. Kumar SV, Venkateswarlu B, Sasikala M, Kumar GV. A study on poisoning cases in a tertiary care hospital. J Nat Sci Biol Med. 2010;1(1):35.

99. Peter JV, Jerobin J, Nair A, Bennett A, Samuel P, Chrispal A, et al. Clinical profile and outcome of patients hospitalized with dimethyl and diethyl organophosphate poisoning. Clin Toxicol. 2010;48(9):916-23.

100. Cherukuri H, Pramoda K, Rohini D, Thunga G, Vijaynarayana K, Sreedharan N, et al. Demographics, clinical characteristics and management of herbicide poisoning in tertiary care hospital. Toxicol Int. 2014;21(2):209.

101. Bose A, Sandal Sejbaek C, Suganthy P, Raghava V, Alex R, Muliyil J, et al. Self-harm and self-poisoning in southern India: choice of poisoning agents and treatment. Tropical Med Int Health. 2009;14(7):761-5.

102. Sweni S, Meenakshisundaram R, Sakthirajan R, Rajendiran C, Thirumalaikolundusubramanian P. Acute renal failure in acute poisoning: prospective study from a tertiary care Centre of South India. J Renal Care. 2012;38(1):22-8.

103. Sharma A, Dishant VG, Kaushik JS, Mittal K. Aluminum phosphide (celphos) poisoning in children: a 5-year experience in a tertiary care hospital from northern India. Indian J Crit Care Med. 2014;18(1):33.

104. Mohan B, Singh B, Gupta V, Ralhan S, Gupta D, Puri S, et al. Outcome of patients supported by extracorporeal membrane oxygenation for aluminum phosphide poisoning: an observational study. Indian Heart J. 2016;68(3): 295-301.

105. Ahuja H, Mathai AS, Pannu A, Arora R. Acute poisonings admitted to a tertiary level intensive care unit in northern India: patient profile and outcomes. J Clin Diagn Res. 2015;9(10):UC01.

106. Raizada A, Kalra OP, Khaira A, Yadav A. Profile of hospital admissions following acute poisoning from a major teaching hospital in North India. Trop Dr. 2012;42(2):70-3.

107. Singh SP, Aggarwal AD, Oberoi SS, Aggarwal KK, Thind AS, Bhullar DS, et al. Study of poisoning trends in North India-a perspective in relation to world statistics. J Forensic Legal Med. 2013;20(1):14-8.

108. Kumar S, Verma AK, Ali W, Pandey A, Ahmad I, Singh US. A study of unnatural female death profile in Lucknow, India. Am J Forensic Med Pathol. 2013;34(4):352-6.

109. Sibia R, Kumar S, Bhullar D, Pillai G, Sharma H, Sandhu S. Poisoning trends at a tertiary hospital: a retrospective analysis. J Punjab Acad Forensic Med Toxicol. 2014;14(1):19-21.

110. Sharma A, Balasubramanian P, Gill KD, Bhalla A. Prognostic significance of blood glucose levels and alterations among patients with aluminium phosphide poisoning. Sultan Qaboos Univ Med J. 2018;18(3):e299.

111. Parekh U, Gupta S. Epidemio-toxicological profile of poisoning cases-a five years retrospective study. J Forensic Legal Med. 2019;65:124-32.

112. Kumar S, Verma A. A study of elderly unnatural deaths in medico-legal autopsies at Lucknow locality. Med Sci Law. 2014;54(3):127-31.

113. Swain R, Singh S, Krishna K, Behera C, Mallick S, Bhardwaj D. Fatal dextropropoxyphene poisoning an autopsy study of 11 cases. J Indian Acad Forensic Med. 2014;36(1):34-7.

114. Parekh U, Gupta S. Kerosene-a toddler's sin: A five years study at tertiary care hospital in western India. J Forensic Legal Med. 2017;47:24-8. 
115. Lakshmi P, Sharma A, Bhatia D, Tikoo K, Kumar R. Dropsy outbreak in a single family in Punjab, India. Am J Trop Med Hyg. 2014;91(4):786-9.

116. Krause KH, van Thriel C, De Sousa PA, Leist M, Hengstler JG. Monocrotophos in Gandaman village: India school lunch deaths and need for improved toxicity testing. Arch Toxicol. 2013;87(10):1877-81.

117. Gangal R, Haroon A. Profile of acute poisoning in paediatric age in district Moradabad: a hospital based study. J Indian Acad Forensic Med. 2015;37(2): 155-9.

118. Singh J, Kaur J, Kumar V, Shah K, Tandon R, Patil V. Trends of poisoning in a tertiary care Centre of north West Uttar Pradesh. J Indian Acad Forensic Med. 2015;37(4):396-9.

119. Haloi M, Haloi MD, Patowary A. Death due to poisoning in district of Kamrup, Assam a medico-legal study. J Indian Acad Forensic Med. 2013; 35(1):17-20

120. Joshi SC, Prakash C, Joshi A, Joshi G. Profile of organophosphorus poisoning at tertiary care hospital in Uttarakhand. J Indian Acad Forensic Med. 2013; 35(4):346-8.

121. Paul UK, Bhattacharyya AK. ECG manifestations in acute organophosphorus poisoning. J Indian Med Assoc. 2012;110(2):98 107-108.

122. Debata PK, Deswal S, Kumath M. Causes of unnatural deaths among children and adolescents in northern India-a qualitative analysis of postmortem data. J Forensic Legal Med. 2014;26:53-5.

123. Sharma S, Kumar K, Bhargava S, Jamwal V, Sharma A, Singh R. Data in support of poisoning related mortalities from southern Himachal Pradesh. Data in brief. 2017;12:493-8.

124. Sikary AK, Sasidharan A, Pillay V, Andrade C. Prescription drug suicide in non-abusers: a 6-year forensic survey. Asian J Psychiatr. 2019:44:133-7.

125. Bammigatti C, Surynarayana B, Kumar KH, Kumar SG. Pattern and outcome of Cleistanthus collinus (Oduvanthalai) poisoning in a tertiary care teaching hospital in South India. J Forensic Legal Med. 2013;20(8):959-61.

126. Balasubramanian D, Subramanian S, Shanmugam K. Clinical profile and mortality determinants in hair dye poisoning. Ann Niger Med. 2014;8(2):82

127. Alugonda $Y$, Maddileti B, Lingam JN, Rangaiah $Y$. A medico-legal study of hair dye poisoning. J Indian Acad Forensic Med. 2013;35(3):251-4.

128. Kondle R, Pathapati RM, Saginela SK, Malliboina S, Makineedi VP. Clinical profile and outcomes of hair dye poisoning in a teaching hospital in Nellore. ISRN emerg med. 2012;2012.

129. Sanchez L, Handyal H, Kannan S. Hair dye poisoning: retrospective analyses of patients admitted to ICU at a rural hospital in India. Indian J Med Res. 2016;144(1):134.

130. Panda BB, Hansda MK, Mishra K, Samantsinghar P. Study of poisoning cases in an Indian tertiary care teaching hospital. J Indian Acad Forensic Med. 2015:37(2):165-8.

131. Thakur S, Gurbani V. Study of acute poisoning cases in a tertiary Care Hospital of South-Eastern Odisha. J Indian Acad Forensic Med. 2017;39(2): 184-9.

132. Katageri S, Singh AK, Govindaraju H, Sharma RB. Study of poisoning cases in Chitradurga district. J Indian Acad Forensic Med. 2016;38(2):179-81.

133. Das Adhikari D, Das S, Winston AB, Vazhudhi K, Kumar A, Shanthi FXM, et al. A retrospective study on non-drug related poisoning in the community among children from South India. Hosp Pract. 2017;45(2):39-45.

134. Veeresh M, Chidananda P. Organo-chlorine esticide fatalities-A retrospective study. Indian J Forensic Med Toxicol. 2013;7(1):254-87.

135. Indira M, Andrews M, Rakesh T. Incidence, predictors, and outcome of intermediate syndrome in cholinergic insecticide poisoning: a prospective observational cohort study. Clin Toxicol. 2013;51(9):838-45.

136. Suma T. Pattern of poisoning in a tertiary care center with special reference to Odollam poisoning. J Assoc Physicians India. 2019;67(3):64-6.

137. Gopal B, Viswakanth B, Shruthi P, Varma R. A retrospective analysis of suicidal poisoning deaths in a metropolitan city of South India. J Indian Acad Forensic Med. 2015;37(2):140-3.

138. Satish N, Shivaramu M, Ramadasan J. A study pattern of poisoning among the autopsies conducted at Adichunchanagiri institute of medical sciences. Medico-Legal Update. 2019;19(1):61-4.

139. Kumar RR, Chandrashekaraiah C. Patterns of fatal poisoning deaths: a retrospective study. J Punjab Acad Forensic Med Toxicol. 2014;14(2):91-5.

140. Viswanathan K, Gupta A, Santhosh C, Siddesh R, Prabal S. Profile of fatal organophosphorus pesticide poisoning cases near Davangere. J Punjab Acad Forensic Med Toxicol. 2014;14(2):96-100.

141. Madhavan I, Kareparambil Balan R, Neeratty Asokan B, Mekkattukunne Andrews A, Valliot A. A retrospective analysis of pattern of suicide in autopsied cases in a tertiary care hospital. Asia Pac J Med Toxicol. 2019;8(2): 45-9.

142. Churi S, Bhakta K, Madhan R. Organophosphate poisoning: prediction of severity and outcome by Glasgow coma scale, poisoning severity score, acute physiology and chronic health evaluation II score, and simplified acute physiology score II. J Emerg Nurs. 2012;38(5):493-5.

143. Indu T, Raja D, Ponnusankar S. Toxicoepidemiology of acute poisoning cases in a secondary care hospital in rural South India: a five-year analysis. J Postgrad Med. 2015;61(3):159.

144. Prasad DR, Jirli PS, Mahesh M, Mamatha S. Relevance of plasma cholinesterase to clinical findings in acute organophosphorous poisoning. Asia Pac J Med Toxicol. 2013;2(1):23-7.

145. Khadilkar NP, Nagesh K, Rai P, Varghese A, Surana N. Hepatic injury in poisoning cases: an autopsy study. J Indian Acad Forensic Med. 2016;38(1): 59-62.

146. Patnaik A, Naik JM, Rao VN, Kumar C, Mahapatra S. A study of pattern of poisoning cases admitted to maharaja Institute of Medical Sciences, Vizianagaram, South India. J Indian Acad Forensic Med. 2016;38(2):182-4.

147. Kanchan T, Bakkannavar SM, Acharya PR. Paraquat poisoning: analysis of an uncommon cause of fatal poisoning from Manipal, South India. Toxicol Int. 2015;22(1):30.

148. Pavan M. Acute kidney injury following Paraquat poisoning in India. Iran J Kidney Dis. 2013;7(1):64-6.

149. Mishra AK, Devakiruba NS, Jasmine S, Sathyendra S, Zachariah A, lyadurai R. Clinical spectrum of yellow phosphorous poisoning in a tertiary care Centre in South India: a case series. Trop Dr. 2017;47(3):245-9.

150. Waghmare S, Mohite S. Gross andistopathological changes in fatal poisoning. J Indian Acad Forensic Med. 2014;36(3):251-4.

151. Saxena V, Atal D, Das $S$. Retrospective analysis of pattern of poisoning in Uttarakhand. J Indian Acad Forensic Med. 2014;36(3):230-3.

152. Banerjee I, Tripathi S, Roy AS. Clinico-epidemiological characteristics of patients presenting with organophosphorus poisoning. N Am J Med Sci. 2012;4(3):147

153. Biswas S, Haldar M, Mondal KK, Dalai CK, Bhattacharyya S, Chatterjee S, et al. Rationally used antidotes in organophosphorus poisoning prevents suicidal death. J Indian Acad Forensic Med. 2013;35(1):51-4.

154. Banerjee I, Tripathi S, Roy AS. Efficacy of pralidoxime in organophosphorus poisoning: revisiting the controversy in Indian setting. J Postgrad Med. 2014 60(1):27.

155. Datir S, Petkar M, Farooqui J, Makhani C, Hussaini SN, Chavan K, et al. Profile of acute poisoning cases at pravara rural hospital, Loni. J Indian Acad Forensic Med. 2015;37(4):400-4.

156. Mori RK, Raloti S, Shah K, Momin S, Shah JV, Patel DS. Pattern of unnatural female deaths at mortuary of civil hospital, Ahmedabad. J Indian Acad Forensic Med. 2017;39(3):287-91.

157. Pate RS, Rojekar MV, Hire RC. Trends of poisoning cases in tertiary care teaching hospitals in western Indian population. Int J Med Toxicol Forensic Med. 2017;7(3 (Summer)):177-84.

158. Zine K, Sane MR, Mugadlimath AB. Homicidal insecticide poisoning in human sacrifice proved on exhumation. J indian soc toxicol. 2014;10(1):458.

159. Ubedullah SK. Organophosphorus compound cocktails. In: APICON 2014, vol. 62. New Delhi: JAPI; 2014. p. 1-206.

160. Shankaragouda BH, Savadkar A, Barjatya HC. Correlation between pop scale and serum cholinesterase in organophosphorus poisoning. In: APICON 2014 vol. 62. New Delhi: J Assoc Physicians India; 2014. p. 1-206.

161. Basha N. Paraquet, a fatal poison - A prospective study. In: APICON 2016, vol. 64. New Delhi: JAPI; 2016. p. 1-208.

162. Jagadeesan, Narayanan N, Muralidharan. Case series of paraquat poisoning: a cross sectional study. In: APICON 2014, vol. 62. New Delhi: JAPI; 2014. p. $1-206$.

163. Paritekar AA, Waikar AK, Borse R, Tamberi DB, Bansode. Study of clinical profile of all poisonings admitted in RCSM GMC Kolhapur (MS). In: APICON 2015, vol. 63. New Delhi: JAPI; 2015. p. 1-208.

164. Safwan A, Rahul K, Inbanathan J. A study of simplified acute physiological score (SAPS II) in the prediction of acute aluminium phosphide poisoning outcome in MICU of a tertiary care hospital. In: APICON 2015, vol. 63. New Delhi: JAPI; 2015. p. 1-208.

165. Naik SC, Mohan A, Kumar SBKVSS, Kumar PD, Harikrishna JMHR. Clinical presentation and predictors of outcome in patients with cleistanthus collinus poisoning. In: APICON 2013, vol. 61. New Delhi: JAPI; 2013. p. 1-196. 
166. Suneetha P, Mohan A, Naik GS, Harikrishna J, Kumar DP, Sarma KVS. Predictors of outcome in patients with super vasmol 33 hair dye poisoning. In: APICON 2014, vol. 62. New Delhi: JAPI; 2014. p. 1-202.

167. Behera C, Krishna K, Bhardwaj DN, Rautji R, Kumar A. A case of accidental fatal aluminum phosphide poisoning involving humans and dogs. J Forensic Sci. 2015;60(3):818-21.

168. Agrawal VK, Bansal A, Singh RK, Kumawat BL, Mahajan P. Aluminum phosphide poisoning: possible role of supportive measures in the absence of specific antidote. Indian J Crit Care Med. 2015;19(2):109.

169. Bansal A, Gupta R, Singh P, Kaur K, Kaur D, Kaur G, et al. Poisoning pattern in the cases reported by chemical examiner laboratory-Punjab, India. J Indian Acad Forensic Med. 2018;40(4):349-51.

170. Gupta B, Kishore K, Rastogi P, Singh R. Retrospective study of poisoning cases at tertiary care hospital in western Uttar Pradesh. J Indian Acad Forensic Med. 2016;38(1):11-4.

171. Ali I, Sawlani KK, Himanshu D, Chaudhary SC, Usman K, Atam V, et al. Study of pattern and outcome of acute poisoning cases at tertiary care hospital in North India. J Evid Based Med Healthc. 2017;4(6):2349-570.

172. Alam S, Khanna R, Sood V, Lal BB, Rawat D. Profile and outcome of first 109 cases of paediatric acute liver failure at a specialized paediatric liver unit in India. Liver Int. 2017;37(10):1508-14.

173. Kumar A, Sood V, Khanna R, Verma SK, Mehra N, Rawat D, et al. Clinical spectrum and outcome of pediatric drug induced liver injury. Indian J Pediatr. 2018;85(8):676-8.

174. Alam F, Aziz UBA, Aslami AN. Endosulfan toxicity: a retrospective study and review. J Indian Acad Forensic Med. 2017;39(1):63-6.

175. Kaeley N, Bhushan B, Subramanyam V, Kumar S, Kabi A. Clinical and demographic characteristics of geriatric patients with acute poisoning in the state of Uttarakhand. J Family Med Prim Care. 2019;8(2):443.

176. Raghapriya R, Dosi RV, Parmar A. Glycemic status at the time of presentation in acute organophosphorous poisoning and its correlation with severity and clinical outcome. J Assoc Physicians India. 2018;66:18.

177. Awasthi P, Dev R, Verma S, Pathak A, Bajpai A, Bharti A, et al. Medico-legal evaluation of death due to poisoning. Indian J Forensic Med Toxicol. 2019; 13(1):52-6.

178. Richardson M. Pesticides-friend or foe? Water Sci Technol. 1998:37(8):19-25.

179. Lad K, Patel V, Parmar P. Profile study of organophosphorus poisoning at Valsad: a 2 year study. J Indian Acad Forensic Med. 2017;39(3):235-8.

180. Bhowmick K, Ghosh B, Pain S. A study on deliberately self-poisoned inhospital patients in a tertiary health care center in Northeast India: a crosssectional review. J Emerg Med. 2019;56(5):512-8.

181. Kariyappa M, Kejjaiah AK, Ramachandrappa RS, Benakappa A. Phosphide poisoning in children in tertiary care hospital of South India: a retrospective study. Int J Sci Study. 2015;3(6):5-9.

182. Menon MS, Kumar $P$, Jayachandran C. Clinical profile and management of poisoning with suicide tree: an observational study. Heart Views. 2016;17(4): 136.

183. Benjamin RN, David T, Iyadurai R, Jacob K. Suicidal nonorganophosphate poisoning in a tertiary hospital in South India: nature, prevalence, risk factors. Indian J Psychol Med. 2018;40(1):47.

184. Patil G, Murthy N, Nikhil M. Contributing factors for morbidity and mortality in patients with organophosphate poisoning on mechanical ventilation: a retrospective study in a teaching hospital. J Clin Diagn Res. 2016;10(12):UC18.

185. Selvaraj T, Sudharson T. Demographic and clinical profile of organophosphorus poisoning cases in a medical college hospital, Tamil Nadu. Indian J Forensic Community Med. 2016;3(2):124-7.

186. Mohite PM, Anjankar A, Patnod S. Organo phosphorus poisoning: prognostic value of GCS score \& other clinical indicators in assessing the final outcome. J Indian Acad Forensic Med. 2018;40(2):197-205.

187. Banday TH, Tathineni B, Desai MS, Naik V. Predictors of morbidity and mortality in organophosphorus poisoning: a case study in rural hospital in Karnataka, India. N Am J Med Sci. 2015;7(6):259.

188. Muthukulla J. Study of blood sugar level as a prognostic indicator in organ phosphorus compound poisoning. J Assoc Physicians India. 2016;64(1):65.

189. Tripathy S, Rout P, Debta N, Das S, Panigrahi M, Mishra S, et al. Study of clinical profile of organophosphorus poisoning with special reference to electrocardiographic changes and electrolyte derangement. Int J Adv Med. 2018;18(5):1

190. Mural R, Bajaj G, Mammen D. Study of level of total serum creatine phosphokinase as prognostic indicator in acute organophosphorus poisoning: a prospective study. Int Jo Contemp Med Res. 2017:4(2):578-82
191. Asawari R, Atmaram P, Bhagwan K, Priti D, Kavya S, Jabeen GA. Toxicological pattern of poisoning in urban hospitals of western India. J Young Pharm. 2017;9(3):315.

192. Rajesh JJ, Rakesh JG, Chander U, Kumar PS. A prospective study of poisoning cases due to paraquat at a tertiary care Centre-Chennai. J Indian Acad Forensic Med. 2016;38(4):397-9.

193. Rao R, Bhat R, Pathadka S, Chenji SK, Dsouza S. Golden hours in severe paraquat poisoning-the role of early haemoperfusion therapy. J Clin Diagn Res. 2017;11(2):OC06.

194. Bhadade R, deSouza R, Gangawane S. Analysis of poisoning in urban setting: A single centre study. J Assoc Physicians India. 2019;67:57.

195. Sugunan S, Krishnan R, Kumar KS, Geetha S. Rodenticide poisoning in children: a study of clinical profile and electrocardiographic changes. Indian J Child Health. 2017;4(2):136-9.

196. Suganthi R, Nagarajan K. Rodenticide (yellow phosphorous) poisoning outcome. J Assoc Physicians India. 2016;64(1):65.

197. Das M, Nath BK, Bhattacharjee P, Das P. Clinico-etiological profile of poisoning in a tertiary care hospital of north-eastern India. In: APICON 2017, vol. 65. New Delhi: JAPI; 2017. p. 1-180.

198. Man Mohan US, Ravi BN, Naik HV. Study of hyperglycemia in correlation with pseudocholinesterase levels and severity of organophosphorous poisoning. In: APICON 2017, vol. 65. New Delhi: JAPI; 2017. p. 1-180.

199. Sandeep R, Keshava HK, Channaraya V. Comparative study of poisoning severity score, Apache 2, glasgow coma scale in predicting severity and clinical outcome in acute organophosphorous poisoning. In: APICON 2018, vol. 66. New Delhi: JAPl; 2018. p. 1-210.

200. Harish P, Rajarao M, Sekhar VA, Chander BT. Study of QTc interval as a prognostic marker in OP poisioning patients. In: APICN 2019, vol. 67. New Delhi: JAPl; 2019. p. 1-196.

201. Pathi D, Tripathy KP, Behera PK, Panda SS, Patro S, Acharya S. Paraquat- a lethal herbicide: a case series. In: APICON 2019, vol. 67. New Delhi: JAPI; 2019. p. 1-196.

202. Tiwari A, Singh VB, Singla R, Meena BL, Singh D, RajkumarLakhiwal. Clinical profile of organophosphorus poisoning and importance of serum creatinine phosphokinase levels as prognostic marker. In: APICON 2018, vol. 66. New Delhi: JAPI; 2018. p. 1-220.

203. Bonvoisin T, Utyasheva L, Knipe D, Gunnell D, Eddleston M. Suicide by pesticide poisoning in India: a review of pesticide regulations and their impact on suicide trends. BMC Public Health. 2020;20(1):1-16.

204. Agricultural \& Processed Food Products Exports Development Authority, Government of India. Wheat. Webpage. 2019. https://apeda.gov.in/apeda website/SubHead_Products/Wheat.htm. Accessed 14 June 2021.

205. Dandona R, Bertozzi-Villa A, Kumar GA, Dandona L. Lessons from a decade of suicide surveillance in India: who, why and how? Int J Epidemiol. 2017; 46(3):983-93.

206. World Health Organization: Detoxifying agriculture and health from highly hazardous pesticides: a call for action. 2019.

207. World Health Organization: Preventing suicide: a resource for pesticide registrars and regulators. 2019.

208. World Health Organization: Safer access to pesticides: community interventions. 2006.

209. Food and Agriculture Organization of the United Nations, World Health Organization. International Code of Conduct on Pesticide Management: Guidelines on Highly Hazardous Pesticides. FAO: Rome; 2016.

210. Eddleston M, Karalliedde L, Buckley N, Fernando R, Hutchinson G, Isbister G, et al. Pesticide poisoning in the developing world - a minimum pesticides list. Lancet. 2002;360(9340):1163-7.

211. Gunnell D, Knipe D, Chang S-S, Pearson M, Konradsen F, Lee WJ, et al. Prevention of suicide with regulations aimed at restricting access to highly hazardous pesticides: a systematic review of the international evidence. Lancet Glob Health. 2017;5(10):e1026-37.

212. Fernando R. The national poisons information Centre in Sri Lanka: the first ten years. J Toxicol Clin Toxicol. 2002;40(5):551-5.

213. Schurter D, Rauber-Lüthy C, Jahns M, Haberkern M, Kupferschmidt $H$, Exadaktylos A, Eriksson U, Ceschi A. Factors that trigger emergency physicians to contact a poison centre: findings from a Swiss study. Postgrad Med J. 2014;90(1061):139-43.

214. Fountain JS, Slaughter RJ. TOXINZ, the New Zealand internet poisons information database: the first decade. Emerg Med Australas. 2016;28(3):335-40.

215. National Poisons Information Service of the United Kingdom. National poison information service annual report 2018/2019, vol. 16; 2019. https:// 
www.npis.org/Download/NPISAnnualReport2018-19.pdf. Accessed 14 June 2021.

216. Abou-Auda HS. Information-seeking behaviors and attitudes of physicians toward drug information centers in Saudi Arabia. Saudi Med J. 2008;29(1): 107.

217. Jayaraman KS. Death pills from pesticide. Nature. 1991;353(6343):377.

218. Banjaj R, Wasir H. Epidemic aluminium phosphide poisoning in northern India. Lancet (London, England). 1988;1 (8589):820.

219. Kabra S, Narayanan R. Aluminium phosphide: worse than Bhopal. Lancet. 1988;1 (8598):1333.

220. Chugh S, Ram S, Arora B, Malhotra K. Incidence \& outcome of aluminium phosphide poisoning in a hospital study. Indian J Med Res. 1991;94:232-5.

221. Etemadi-Aleagha A, Akhgari M, Iravani FS. Aluminum phosphide poisoningrelated deaths in Tehran, Iran, 2006 to 2013. Medicine. 2015;94(38):e1637

222. Knipe DW, Gunnell D, Eddleston M. Preventing deaths from pesticide selfpoisoning_learning from Sri Lanka's success. Lancet Glob Health. 2017;5(7): e651-2.

223. Gunnell D, Fernando R, Hewagama M, Priyangika W, Konradsen F, Eddleston M. The impact of pesticide regulations on suicide in Sri Lanka. Int J Epidemiol. 2007;36(6):1235-42.

224. Roberts DM, Karunarathna A, Buckley NA, Manuweera G, Sheriff M, Eddleston M. Influence of pesticide regulation on acute poisoning deaths in Sri Lanka. Bull World Health Organ. 2003;81:789-98.

225. Chowdhury FR, Dewan G, Verma VR, Knipe DW, Isha IT, Faiz MA, et al. Bans of WHO class I pesticides in Bangladesh—suicide prevention without hampering agricultural output. Int J Epidemiol. 2018;47(1):175-84.

226. Dawson A, Fahim M, Gawarammana I, Buckley N, Eddleston M, Manuweera G. Relative toxicity of pesticides in the developing world. New York: Informa Healthcare; 2008. p. 403-4.

227. Manuweera G, Eddleston M, Egodage S, Buckley NA. Do targeted bans of insecticides to prevent deaths from self-poisoning result in reduced agricultural output? Environ Health Perspect. 2008;116(4):492-5.

228. Indian Council of Agricultural Research. Report of the special committeeon harmful effects of pesticides. New Delhi: ICAR; 1967.

229. Editorial. Phasing out harmful use of pesticides. Lancet. 2017;389:1069.

230. World Health Organization. Health implications from monocrotophos use: a review of the evidence in India: WHO Regional Office for South-East Asia; 2009.

231. Department Of Agriculture, Co-Operation and Farmers Welfare, Ministry of Agriculture and Farmers Welfare, Government of India. Pesticides (Prohibition) order, 2018. New Delhi, India; 2018.

232. Kapil S. Maharasthra consumed the most chemical pesticides in 5 years: Report. Downtoearth. [https://www.downtoearth.org.in/news/agriculture/ma harashtra-consumed-the-most-chemical-pesticides-in-5-years-report-69880] Accessed 14 June 2021.

233. Jayaraj R, Megha P, Sreedev P. Organochlorine pesticides, their toxic effects on living organisms and their fate in the environment. Interdiscip Toxicol. 2016;9(3-4):90-100.

234. Kumar ADD, Jayakumar C. From precautionary principle to nationwide ban on endosulfan in India. Bus Hum Rights J. 2019;4(2):343-9.

235. Jagadeesan M, Nithyananthan P, Banupriya M, Mahendrakumar K, Prasanna K, Kannan R. A study on clinical profile of paraquat poisoning in a tertiary care hospital. Int J Adv Med. 2017;4:1088-91.

236. There's no antidote to paraquat herbicide, ban it: Odisha docs to govt [https://www.downtoearth.org.in/news/agriculture/there-s-no-antidote-to-pa raquat-herbicide-ban-it-odisha-docs-to-govt-66779]. Accessed 14 June 2021.

237. Jones CM, Mack KA, Paulozzi LJ. Drug Involvement in Pharmaceutical Overdose Deaths. JAMA. 2013;309(7):657.

238. de Silva VA, Senanayake S, Dias P, Hanwella R. From pesticides to medicinal drugs: time series analyses of methods of self-harm in Sri Lanka. Bull World Health Organ. 2012;90:40-6.

239. Opioid addiction rising in India as US drugmakers push painkillers [https:// www.theguardian.com/world/2019/aug/28/india-opioids-addiction-usdrugmakers-push-painkillers]. Accessed 14 June 2021.

240. Balhara YPS. Dextropropoxyphene ban in India: is there a case for reconsideration? J Pharmacol Pharmacother. 2014;5(1):8.

241. World Health Organization: The impact of pesticides on health. In: www who int/mental_health/prevention/suicide/en/Pesticideshealth2 pdf. World Health Organization; 2004.
242. Joseph A, Abraham S, Muliyil J, George K, Prasad J, Minz S, et al. Evaluation of suicide rates in rural India using verbal autopsies, 1994-9. BMJ. 2003; 326(7399):1121-2.

\section{Publisher's Note}

Springer Nature remains neutral with regard to jurisdictional claims in published maps and institutional affiliations.
Ready to submit your research? Choose BMC and benefit from:

- fast, convenient online submission

- thorough peer review by experienced researchers in your field

- rapid publication on acceptance

- support for research data, including large and complex data types

- gold Open Access which fosters wider collaboration and increased citations

- maximum visibility for your research: over $100 \mathrm{M}$ website views per year

At BMC, research is always in progress.

Learn more biomedcentral.com/submissions 